\title{
Nutritional value of non-conventional vegetables prepared by family farmers in rural communities
}

\author{
Heliane Aparecida Barros de Oliveira ${ }^{1}$ Pamella Cristine Anunciação $^{1 *}$ (D) Bárbara Pereira da Silva ${ }^{2}$ \\ Ângela Maria Natal de Souza $^{1}$ Soraia Silva Pinheiro ${ }^{1}$ Ceres Mattos Della Lucia ${ }^{1}$ \\ Leandro de Morais Cardoso ${ }^{2}$ Luiza Carla Vidigal Castro' ${ }^{1}$ Helena Maria Pinheiro-Sant'Ana ${ }^{1}$
}

\footnotetext{
${ }^{1}$ Departamento de Nutrição e Saúde, Universidade Federal de Viçosa (UFV), Viçosa, MG, Brasil.

Departamento de Nutrição, Universidade Federal de Juiz de Fora (UFJF), Campus Governador Valadares, 36570-900, Governador Valadares, MG, Brasil. E-mail: nutripamella@gmail.com. "Corresponding author.
}

\begin{abstract}
Four most consumed non-conventional vegetables were analyzed raw and after cooking techniques routinely used by family farmers: ora-pro-nobis (Pereskia aculeata Mill.); wild mustard (Sinapis arvensis L.), serralha (Sonchus arvensis L), and capiçova (Erechtites valeriana). Chemical composition was determined according to AOAC. Vitamin $C$, vitamin E and carotenoids were determined by highperformance liquid chromatography, and phenolic compounds and minerals by spectrophotometry. Vitamin E and carotenoids concentrations were higher in stir fried wild mustard (7.68 $\mathrm{mg}^{1} 100 \mathrm{~g} \mathrm{~g}^{-1}$ and $7.45 \mathrm{mg} 100 \mathrm{~g}^{-1}$, respectively). Cooking reduced some minerals concentration in the non-conventional vegetables, but increased vitamins and carotenoids concentrations. The vegetables presented high content of minerals but low protein concentration and total energy content. Non-conventional vegetables can be considered of excellent nutritional value and frequent consumption of these vegetables can contribute to improve the feeding of farmers and their families.

Key words: vitamins, HPLC, agroecology, food sovereignty.
\end{abstract}

Valor nutricional de hortaliças não convencionais preparadas por agricultores familiares em comunidades rurais

RESUMO: Quatro hortaliças não convencionais mais consumidas foram analisadas cruas e após as técnicas de cocção utilizadas rotineiramente pelos agricultores familiares: ora-pro-nobis (Pereskia aculeata Mill.); mostarda selvagem (Sinapis arvensis L.), serralha (Sonchus arvensis L) e capiçova (Erechtites valeriana). A composição química foi determinada de acordo com a AOAC. A vitamina $C$, vitamina $E$ e os carotenoides foram determinados por cromatografia líquida de alta eficiência (CLAE), e compostos fenólicos e minerais foram determinados por espectrofotometria. As concentrações de vitamina E e carotenoides foram maiores na mostarda selvagem $\left(7,68 \mathrm{mg} .100 \mathrm{~g}^{-1}\right.$ e 7,45 mg.100 $\mathrm{g}^{-1}$, respectivamente). A cocção reduziu a concentração de alguns minerais nas hortaliças não convencionais, mas aumentou as concentrações de vitaminas e carotenoides. As hortaliças apresentaram alto teor de minerais, mas baixa concentração protéica e valor energético total. As hortaliças não convencionais podem ser consideradas de excelente valor nutricional. O consumo frequente dessas hortaliças pode contribuir para melhorar a alimentação dos agricultores e suas famílias. Palavras-chave: vitaminas, CLAE, agroecologia, soberania alimentar.

\section{INTRODUCTION}

Non-conventional vegetables are of great importance for human feeding since they may provide vitamins, dietary fiber, carbohydrates, minerals and proteins (MAPA, 2010). These foods are considered non-conventional because they are currently consumed by only a few people, usually in restricted areas or communities. In addition, non-conventional vegetables have sensory characteristics that makes their consumption easier (VIANA et al., 2015), and they can be used in raw salads, soups, puree and omelets (KINUPP e LORENZI, 2014). Among these vegetables, ora-pro-nobis (Pereskia aculeata Mill.), wild mustard (Sinapis arvensis L.), serralha (Sonchus arvensis L.) and capiçova (Erechtites valeriana) stand out because they are consumed by rural communities in Brazil. Knowledge about the consumption and preparation of these four vegetables was acquired by parents and grandparents and passed on to children and grandchildren, encouraged by their nutritional and medicinal value (OLIVEIRA et al., 2019). Besides that, the intake of these non-conventional vegetables is associated with antioxidant, anti-inflammatory, 
antimicrobial and anti-cancer effects (MERTZ et al., 2009), that are partially attributed to the biological activities of their phytochemical constituents such as phenolic compounds, vitamins, carotenoids, flavonoids and minerals (PODSĘDEK, 2007).

Keeping the concentrations of vitamins and minerals in vegetables is a challenge, since chemical and physical reactions occur right after harvest and may influence their quality. The processing to which they are subjected before consumption can also change their characteristics (BARRETT et al., 2010). Light, heat, water and oxygen may lead to decomposition and loss of color and nutritive value (CARDOSO et al., 2009). Conversely, cooking may increase bioavailability, especially of carotenoids, and promote reduction of antinutritional factors present in foods (PLATEL \& SRINIVASAN, 2016).

Cooking methods depend on the culture and eating habits of population and communities in each country and region. In addition, the food preparation techniques vary widely between urban and rural areas due to different habits and available equipment and utensils. In the rural area most people use wood stove to make preparations tastier (SOUZA et al., 2003). Thus, the culinary techniques employed in the different cooking methods can influence in a different way the nutritional value of the foods and, therefore, the amount of nutrients ingested by the different populations.

There are no studies that have evaluated the nutritional composition of non-conventional vegetables, prepared according to the techniques used by rural communities in Brazil. Thus, this study aimed to investigate the nutritional value of non-conventional vegetables in communities of a rural area of Brazil, as well as to evaluate their potential contribution to the supply of daily nutrient recommendations for adults.

\section{MATERIALS AND METHODS}

\section{Characterization of sampling}

Four non-conventional vegetables most consumed by family farmers in the rural area of Viçosa, Minas Gerais, Brazil (BARREIRA et al., 2015), were selected: ora-pro-nobis (Pereskia aculeata Mill.), wild mustard (Sinapis arvensis L.), serralha (Sonchus arvensis L.) and capiçova (Erechtites valeriana) (Figure 1). Samples were analyzed raw and cooked (stir frying and boiling), prepared by the familiar farmers in their residences. Families were selected as described in our previous study (OLIVEIRA et al., 2019). Then, five families were selected from five different communities, with similarity in the preparation techniques, characterizing five repetitions.
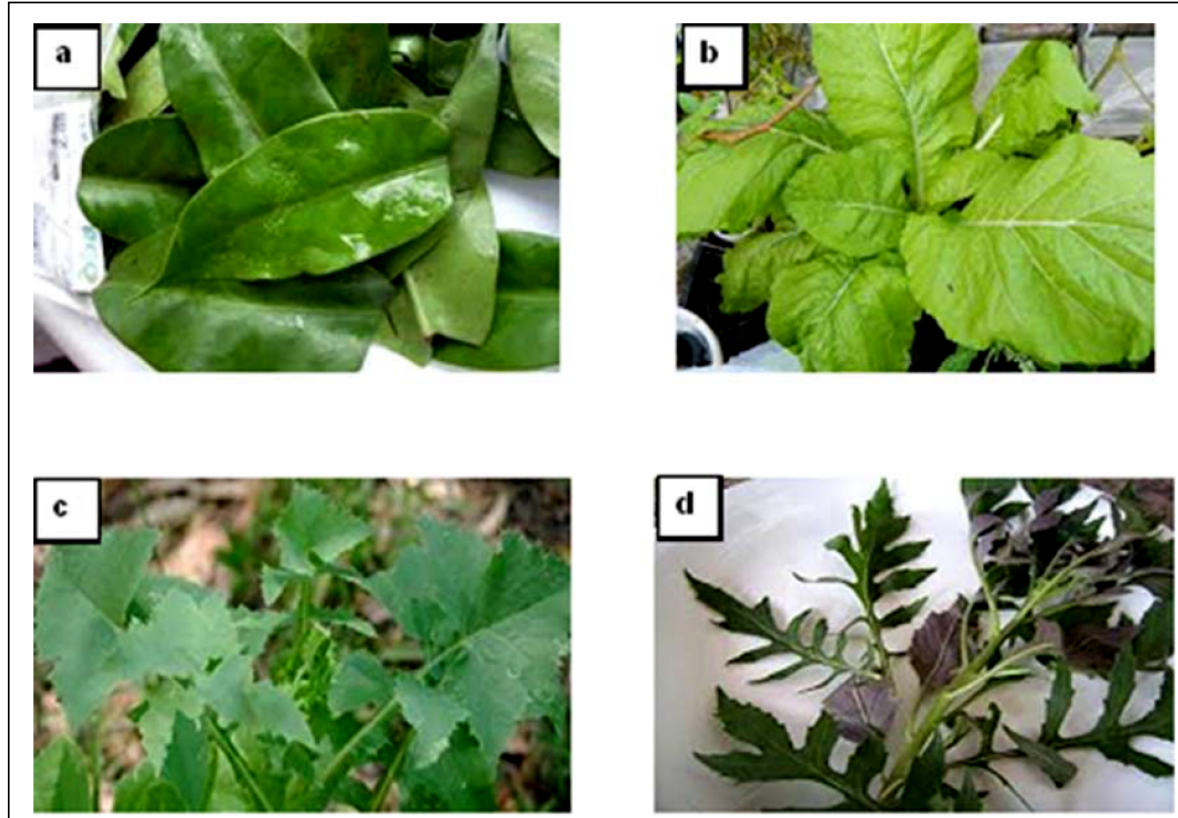

Figure 1 - Non-conventional vegetables: a) ora-pro-nobis (Pereskia aculeata Mill.), b) wild mustard (Sinapis arvensis L.), c) serralha (Sonchus arvensis L.), d) capiçova (Erechtites Valeriana). 
Cooking methods used in the preparation of vegetables

The harvesting, pre-preparation and cooking of non-conventional vegetables carried out by family farmers were accompanied through visits to rural communities. Vegetables and ingredients used in the preparation were weighed in a scale (Bioprecisa, BS 3000), the temperatures were measured in a digital infrared laser thermometer (Matsuri, temperature from $-50{ }^{\circ} \mathrm{C}$ to $320^{\circ} \mathrm{C}$ ) and the preparation time was monitored.

The pre-preparation and cooking techniques and kitchen utensils were those routinely used by the family farmers (OLIVEIRA et al., 2019). Thus, we sought to analyze the nutritional value of non-conventional vegetables in real conditions of preparation and consumption. The pre-preparation stages consisted of washing in tap water, discarding large stalks and old leaves and then slicing them into 3 to $4 \mathrm{~mm}$ pieces. A wood burning stove was used by all families. Stir frying was used, adding the non-conventional vegetables in heated soybean oil (on average $88^{\circ} \mathrm{C}$ ) and spice (garlic and salt), except for ora-pro-nobis, which preparation also involved the addition of water, being characterized as boiling (average temperature of $90{ }^{\circ} \mathrm{C}$ ). Cooking time of ora-pro-nobis, wild mustard and serralha was 4 minutes, and cooking time of capiçova was 6 minutes.

\section{Selection and collection of samples for analysis}

Raw and cooked samples were collected, packed in plastic bags and wrapped in aluminum paper, identified and transported to the laboratory in styrofoam boxes. In the laboratory, samples were stored in hermetically sealed plastic bags, protected from light and frozen $\left(-18 \pm 1{ }^{\circ} \mathrm{C}\right)$ until the time of analysis (maximum of 180 days).

Macronutrients, moisture, ash, total dietary fiber and minerals analysis

The analysis was performed in three repetitions. Moisture, ash, protein and lipids were analyzed according to AOAC (2012). Carbohydrates were calculated as the difference, using the equation: $[100-(\%$ moisture $+\%$ lipids + $\%$ proteins $+\%$ total dietary fiber $+\%$ ash)]. Total energy value of non-conventional vegetables was estimated considering the conversion factors of 4 $\mathrm{kcal} . \mathrm{g}^{-1}$ for protein or carbohydrate and $9 \mathrm{kcal} . \mathrm{g}^{-1}$ for lipid. Concentrations of $\mathrm{P}, \mathrm{K}, \mathrm{Ca}, \mathrm{Cu}, \mathrm{Mn}, \mathrm{Fe}$, $\mathrm{Zn}$ and $\mathrm{Mg}$ were determined according to GOMES \& OLIVEIRA (2011) by inductively coupled plasma atomic emission spectrometry.
Extraction and analysis of carotenoids and vitamins

The analysis was performed in five repetitions. During analysis, the samples and the extracts were protected from sunlight and artificial light and protected from oxygen.

\section{Carotenoids}

Carotenoids were extracted with acetone and petroleum ether in accordance with RODRIGUEZAMAYA (2001). Carotenoids were analyzed using a high-performance liquid chromatography system (HPLC) (Shimadzu, SCL 10AT VP model, Japan) comprised of a high-pressure pump (Shimadzu, LC10AT VP model, Japan), an autosampler with a loop of $500 \mu \mathrm{L}$ (Shimadzu, SIL-10AF model, Japan) and a diode array detector (DAD) (Shimadzu, SPD-M10A model, Japan), scanning of the spectrum from 350 to $600 \mathrm{~nm}$. The following chromatographic conditions were used: column RP-18 (Phenomenex Gemini, 250 $\mathrm{mm} \times 4.6 \mathrm{~mm}, 5 \mu \mathrm{m})$, fitted with a guard column C18 (Phenomenex ODS $4 \mathrm{~mm}$ x $3 \mathrm{~mm}$ ); mobile phase composed of methanol: ethyl acetate: acetonitrile (HPLC grade, Tedia, Brazil) (80:10:10, v/v/v), flow rate of 2.0 $\mathrm{mL} \cdot \mathrm{min}^{-1}$ and injection volume of $50 \mu \mathrm{L}$ (PINHEIROSANT'ANA et al., 1998). The chromatograms were obtained at $450 \mathrm{~nm}$.

\section{Vitamin C}

Vitamin C (in ascorbic acid - AA - form) extraction and analysis were carried out according to CAMPOS et al. (2009), with modifications. Five g of nonconventional vegetables were homogenized for $5 \mathrm{~min}$ with $15 \mathrm{~mL}$ of extraction solution (3\% metaphosphoric acid, $8 \%$ acetic acid, $\mathrm{H}_{2} \mathrm{SO}_{4} 0.3 \mathrm{~N}$ and $1 \mathrm{mMEDTA}$ ) using a micro grinder. The extract was centrifuged $\left(\mathrm{Hermle}^{\mathbb{R}}\right.$, modelo Z216MK, Germany) at $2865 \mathrm{~g}$ for $15 \mathrm{~min}$, and filtered through Buchner funnel using filter paper.

For AA analysis the following conditions were used: column Synergi Hydro RP 18 (100, 250 x $4.6 \mathrm{~mm}, 5 \mu \mathrm{m}$ ), HPLC system (350 to $600 \mathrm{~nm}$ ); mobile phase containing ultrapure water, $1 \mathrm{mM} \mathrm{NaH} \mathrm{PO}_{4}$, $1 \mathrm{mM}$ EDTA and adjusted to $\mathrm{pH} 3.0$ with $\mathrm{H}_{3} \mathrm{PO}_{4}$; flow rate of $1.0 \mathrm{~mL} / \mathrm{min}$ and injection volume of $50 \mu \mathrm{L}$. Chromatograms were obtained at $245 \mathrm{~nm}$.

\section{Vitamin E}

The extraction and analysis of the components of vitamin $\mathrm{E}(\alpha-, \beta-, \gamma$ - and $\delta$ - tocopherols and tocotrienols) were carried out according to PINHEIRO-SANT'ANA et al. (2011) with modifications. Five to ten grams of non-conventional vegetables were weighed and added to $4 \mathrm{~mL}$ of heated ultrapure water $\left(80 \pm 1^{\circ} \mathrm{C}\right)$. Then $10 \mathrm{~mL}$ of isopropyl 
alcohol, $1 \mathrm{~mL}$ of hexane containing $0.05 \%$ BHT, $5 \mathrm{~g}$ of anhydrous sodium sulfate and $25 \mathrm{~mL}$ of extraction solvent mixture (hexane: ethyl acetate, 85:15 v/v) were added. The sample was homogenized using a micro grinder for $1 \mathrm{~min}$. The extract was vacuum filtered on Buchner funnel using filter paper. Then, the extract was concentrated in a rotating evaporator (Tecnal, TE-211, Brazil) $\left(70 \pm 1{ }^{\circ} \mathrm{C}, 2 \mathrm{~min}\right)$, and transferred to a volumetric flask and the volume was completed to $25.0 \mathrm{~mL}$ using the solvent mixture.

The chromatographic conditions used included: HPLC system (Shimadzu, SCL 10AT VP model, Japan); fluorescence detector (Shimadzu, 14 RF10AXL) (290 nm excitation and $330 \mathrm{~nm}$ emission); column Phenomenex Luna Si100 (250 x $4.6 \mathrm{~mm}, 5 \mu \mathrm{m}$ ) coupled with a Si100 Phenomenex guard column $(4 \times 3 \mathrm{~mm})$; mobile phase - hexane: isopropanol: glacial acetic acid (HPLC grade, Tedia, Brazil) (98.9: 0.6: 0.5, v/v/v); flow rate of $1.0 \mathrm{~mL} /$ min; 22 min run time; $5 \mu \mathrm{L}$ (for cooked vegetables) or $10 \mu \mathrm{L}$ (for raw vegetables) were injected for analysis.

\section{Identification and quantification of carotenoids and vitamins}

The identification of the compounds was performed comparing the retention times obtained for standards and samples analyzed under the same conditions. Moreover, the carotenoid was identified by comparing the absorption spectra of the standard solution and the samples, using the DAD. The identified compounds in the vegetables were quantified by external standard curves constructed by injection, in duplicate, of six increasing concentrations of standard solutions.

\section{Determination of the total phenolic compounds}

One gram of non-conventional vegetables was added to $20 \mathrm{~mL}$ of acetone $70 \%$. Then, the suspension was stirred (10 g, $2 \mathrm{~h}$ ) and centrifuged (2865 g, $15 \mathrm{~min}$ ) (Fanem, 206-R, Brazil). The extract was stored in a freezer $\left(-18 \pm 1^{\circ} \mathrm{C}\right)$ until the time of analysis.

The total phenolic compounds content was determined using the Folin-Ciocalteu reagent (SINGLETON et al., 1999). Aliquots of $0.5 \mathrm{~mL}$ of extract were added to $0.5 \mathrm{~mL}$ of Folin-Ciocalteu reagent $(20 \%)$ and $0.5 \mathrm{~mL}$ of sodium carbonate $(7.5 \%)$. The reaction mixture was homogenized by vortex (2865 g, $10 \mathrm{~s})$ and incubated at room temperature (30 $\mathrm{min})$. Reading of absorbance was performed in spectrophotometer (Thermo Scientific, Evolution 606, USA) at $765 \mathrm{~nm}$. Analytical curve of gallic acid $(0.005-0.10 \mathrm{mg} / \mathrm{mL})$ was used to quantify the compounds. Results were expressed in $\mathrm{mg}$ of gallic acid equivalents/g of non-conventional vegetables (mg GAE/g).
Calculation of the potential of nutritional contribution of non-conventional vegetables

The potential of nutritional contribution of the vegetables was calculated based on the references values for a $2000 \mathrm{Kcal}$ diet for energy, macronutrients, vitamins and minerals based on Dietary Reference Intake (DRI) (INSTITUTE OF MEDICINE: FOOD AND NUTRITION BOARD, 2001), considering a portion of vegetables equivalent to $30 \mathrm{kcal}$.

\section{Experimental design and statistical analysis}

A completely randomized design was used. Data relating to vegetables subjected to the same type of treatment (raw or cooked) were subjected to analysis of variance (ANOVA) at the 5\% probability, followed by Tukey's test. In order to evaluate the effects of processing in each vegetable (before and after cooking), the data were submitted to the paired t-test at the 5\% probability level. Statistical analysis was performed using SPSS software, version 20.0.

\section{RESULTS AND DISCUSSION}

\section{Centesimal composition}

There was no difference in moisture and protein content among raw non-conventional vegetables, or significant variation after cooking (Table 1). Moisture content was similar to that reported in another study (PAULA FILHO et al., 2018). In raw vegetables, the protein content $\left(1.8 \mathrm{~g} .100 \mathrm{~g}^{-1}\right.$ to 2.8 g. $\left.100 \mathrm{~g}^{-1}\right)$ was higher than those reported in other study in raw serralha $\left(1.7{\left.\mathrm{~g} .100 \mathrm{~g}^{-1}\right)}\right.$ (JIMOH \& AFOLAYAN, 2011), and similar to that reported for wild mustard (1.97 g. $\left.100 \mathrm{~g}^{-1}\right)$ (PAULA FILHO et al., 2018). The food composition may vary due to its biological nature, so the different levels of protein reported can be explained mainly by the variety, crop, soil, climate, production, etc. (ALVES et al., 2011). Also, cooking may improve or reduce the protein concentration, depending on the temperature used, heating time and the presence or absence of moisture (YOUNG \& PELLETT, 1994).

There was no difference in lipids among raw vegetables (Table 1). The values reported for wild mustard $\left(1.90 \mathrm{~g}^{1} 100 \mathrm{~g}^{-1}\right)$ was higher than those observed by PAULA FILHO et al., (2018) (0.85 g. $\left.100 \mathrm{~g}^{-1}\right)$. MARTINEVSKI et al. (2013) observed lower result $\left(0.2\right.$ g. $\left.100 \mathrm{~g}^{-1}\right)$ in ora-pro-nobis. Cooked vegetables presented higher lipid concentrations than raw vegetables, which can be attributed to the addition of soybean oil during the cooking process. Although, they did not present significant difference, capiçova $\left(5.50 \pm 1.58\right.$ g. $\left.100 \mathrm{~g}^{-1}\right)$, wild mustard $(4.90 \pm$

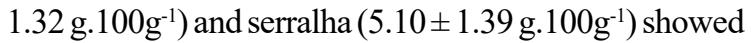


Table 1 - Centesimal composition, minerals and bioactive compounds of raw and cooked ora-pro-nobis and wild mustard by family farmers in the rural area of Viçosa, Minas Gerais, Brazil.

\begin{tabular}{|c|c|c|c|c|}
\hline \multirow[t]{2}{*}{ 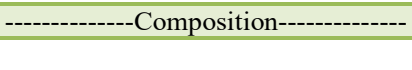 } & \multicolumn{2}{|c|}{ 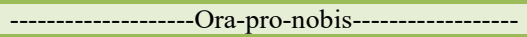 } & \multicolumn{2}{|c|}{-----------------------Wild mustard------------------ } \\
\hline & Raw & Cooked & Raw & Cooked \\
\hline Moisture (g.100g-1) & $87.10 \pm 2.50 \mathrm{Aa}$ & $87.80 \pm 3.30 \mathrm{Aa}$ & $91.60 \pm 1.71 \mathrm{Aa}$ & $87.20 \pm 2.25 \mathrm{Aa}$ \\
\hline Ash (g.100g-1) & $2.90 \pm 0.51 \mathrm{Aa}$ & $3.40 \pm 1.26 \mathrm{Aa}$ & $1.40 \pm 0.25 \mathrm{Bb}$ & $2.00 \pm 0.35 \mathrm{Aa}$ \\
\hline Protein (g.100g-1) & $2.80 \pm 0.11 \mathrm{Aa}$ & $1.90 \pm 0.20 \mathrm{Aa}$ & $2.80 \pm 0.80 \mathrm{Aa}$ & $2.40 \pm 0.55 \mathrm{Aa}$ \\
\hline Lipids (g.100g-1) & $0.40 \pm 0.12 \mathrm{Ba}$ & $2.30 \pm 0.54 \mathrm{Aa}$ & $1.90 \pm 0.68 \mathrm{Ba}$ & $4.90 \pm 1.32 \mathrm{Aa}$ \\
\hline Total carbohydrates (g.100g-1) & $6.70 \pm 1.64 \mathrm{Aa}$ & $4.40 \pm 1.38 \mathrm{Ba}$ & $4.00 \pm 0.74 \mathrm{Aab}$ & $3.20 \pm 1.31 \mathrm{Aa}$ \\
\hline TEV (Kcal.100g-1) & 42 & 47 & 45 & 68 \\
\hline Sum of carotenoids (mg.100g-1) & $3.33 \pm 0.46 \mathrm{Bb}$ & $5.76 \pm 0.98 \mathrm{Aab}$ & $5.15 \pm 0.34 \mathrm{Ba}$ & $7.45 \pm 1.67 \mathrm{Aa}$ \\
\hline Lutein & $2.32 \pm 0.60 \mathrm{Aa}$ & $2.00 \pm 0.28 \mathrm{Aa}$ & $2.81 \pm 0.91 \mathrm{Aa}$ & $2.47 \pm 0.93 \mathrm{Aa}$ \\
\hline$\beta$-carotene & $1.01 \pm 0.38 \mathrm{Bb}$ & $3.60 \pm 0.52 \mathrm{Aa}$ & $2.34 \pm 0.84 \mathrm{Ba}$ & $4.98 \pm 0.78 \mathrm{Aa}$ \\
\hline Vitamin E (mg.100g-1) & $1.39 \pm 0.23 \mathrm{Ba}$ & $4.74 \pm 0.57 \mathrm{Ac}$ & $1.43 \pm 0.14 \mathrm{Bb}$ & $7.68 \pm 1.57 \mathrm{Aa}$ \\
\hline$\alpha$-tocopherol & $1.02 \pm 0.30 \mathrm{Ba}$ & $2.15 \pm 0.66 \mathrm{Aab}$ & $1.14 \pm 0.56 \mathrm{Ba}$ & $2.64 \pm 0.32 \mathrm{Aa}$ \\
\hline$\alpha$-tocotrienol & - & - & - & - \\
\hline$\beta$-tocopherol & $0.03 \pm 0.02 \mathrm{Ba}$ & $0.33 \pm 0.05 \mathrm{Aa}$ & $0.03 \pm 0.01 \mathrm{Ba}$ & $0.19 \pm 0.06 \mathrm{Ab}$ \\
\hline$\beta$-tocotrienol & - & - & - & - \\
\hline$\gamma$-tocopherol & $0.21 \pm 0.06 \mathrm{Ba}$ & $1.58 \pm 0.27 \mathrm{Ab}$ & $0.20 \pm 0.11 \mathrm{Ba}$ & $2.97 \pm 0.76 \mathrm{Aa}$ \\
\hline$\gamma$-tocotrienol & $0.02 \pm 0.01 \mathrm{Aa}$ & $0.03 \pm 0.01 \mathrm{Aa}$ & $0.01 \pm 0.00 \mathrm{Aa}$ & $0.02 \pm 0.00 \mathrm{Aa}$ \\
\hline$\delta$-tocopherol & $0.05 \pm 0.01 \mathrm{Ba}$ & $0.41 \pm 0.09 \mathrm{Ab}$ & $0.01 \pm 0.00 \mathrm{Bb}$ & $1.55 \pm 0.48 \mathrm{Aa}$ \\
\hline$\delta$-tocotrienol & - & - & - & - \\
\hline Total Phenolics (mg GAE.g-1) & $7.86 \pm 1.59 \mathrm{Bb}$ & $42.8 \pm 1.11 \mathrm{Aa}$ & $13.2 \pm 1.36 \mathrm{Ba}$ & $33.9 \pm 1.24 \mathrm{Aa}$ \\
\hline \multicolumn{5}{|l|}{ Minerals (mg.100g-1) } \\
\hline $\mathrm{P}$ & $339.6 \pm 54.3 \mathrm{Aa}$ & $305.8 \pm 79.6 \mathrm{Aa}$ & $451.0 \pm 43.0 \mathrm{Aa}$ & $448.6 \pm 41.2 \mathrm{Aa}$ \\
\hline $\mathrm{K}$ & $3275.2 \pm 811.5 \mathrm{Aa}$ & $2262.0 \pm 628.0 \mathrm{Ba}$ & $3413.0 \pm 585.5 \mathrm{Aa}$ & $2519.0 \pm 278.7 \mathrm{Ba}$ \\
\hline $\mathrm{Ca}$ & $6491.0 \pm 132.5 \mathrm{Aa}$ & $4083.0 \pm 238.5 \mathrm{Ba}$ & $1421.6 \pm 33.3 \mathrm{Ab}$ & $878.8 \pm 156.5 \mathrm{Bb}$ \\
\hline $\mathrm{Mg}$ & $1268.8 \pm 19.7 \mathrm{Aa}$ & $774.2 \pm 32.5 \mathrm{Ba}$ & $267.2 \pm 8.6 \mathrm{Ab}$ & $186.6 \pm 37.0 \mathrm{Bb}$ \\
\hline $\mathrm{Cu}$ & $1.1 \pm 0.3 \mathrm{Aa}$ & $0.7 \pm 0.2 \mathrm{Bab}$ & $0.6 \pm 0.1 \mathrm{Ab}$ & $0.5 \pm 0.0 \mathrm{Ab}$ \\
\hline $\mathrm{Fe}$ & $24.1 \pm 4.1 \mathrm{Ab}$ & $14.2 \pm 2.3 \mathrm{Bb}$ & $62.2 \pm 22.2 \mathrm{Aa}$ & $34.9 \pm 2.7 \mathrm{Bb}$ \\
\hline $\mathrm{Zn}$ & $3.5 \pm 0.7 \mathrm{Aa}$ & $2.3 \pm 0.2 \mathrm{Bb}$ & $4.4 \pm 0.8 \mathrm{Aa}$ & $2.5 \pm 0.7 \mathrm{Bb}$ \\
\hline $\mathrm{Mn}$ & $17.5 \pm 1.7 \mathrm{Aab}$ & $15.2 \pm 11.8 \mathrm{Aa}$ & $4.8 \pm 1.6 \mathrm{Ac}$ & $3.0 \pm 1.0 \mathrm{Bc}$ \\
\hline \multirow[t]{2}{*}{-Mr } & \multicolumn{2}{|c|}{ 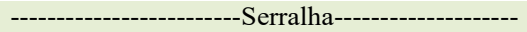 } & \multicolumn{2}{|c|}{ 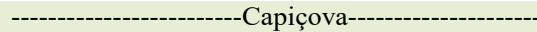 } \\
\hline & Raw & Cooked & Raw & Cooked \\
\hline Moisture (g.100g-1) & $91.50 \pm 0.48 \mathrm{Aa}$ & $86.40 \pm 2.50 \mathrm{Aa}$ & $92.40 \pm 0.78 \mathrm{Aa}$ & $84.40 \pm 4.50 \mathrm{Aa}$ \\
\hline Ash (g.100g-1) & $1.50 \pm 0.03 \mathrm{Bb}$ & $2.60 \pm 0.21 \mathrm{Aa}$ & $1.70 \pm 0.59 \mathrm{Bb}$ & $2.90 \pm 0.71 \mathrm{Aa}$ \\
\hline Protein (g.100g-1) & $2.40 \pm 0.39 \mathrm{Aa}$ & $2.20 \pm 0.58 \mathrm{Aa}$ & $1.80 \pm 0.52 \mathrm{Aa}$ & $2.10 \pm 0.34 \mathrm{Aa}$ \\
\hline Lipids (g.100g-1) & $0.30 \pm 0.06 \mathrm{Ba}$ & $5.10 \pm 1.39 \mathrm{Aa}$ & $0.80 \pm 0.03 \mathrm{Ba}$ & $5.50 \pm 1.58 \mathrm{Aa}$ \\
\hline Total carbohydrates (g.100g-1) & $4.00 \pm 0.49 \mathrm{Aab}$ & $3.50 \pm 1.26 \mathrm{Aa}$ & $3.30 \pm 0.79 \mathrm{Bb}$ & $4.90 \pm 0.92 \mathrm{Aa}$ \\
\hline TEV (Kcal.100g-1) & 29 & 69 & 29 & 78 \\
\hline Sum of carotenoids (mg.100g-1) & $5.39 \pm 0.88 \mathrm{Aa}$ & $6.51 \pm 0.94 \mathrm{Aa}$ & $4.99 \pm 0.66 \mathrm{Aa}$ & $5.22 \pm 0.92 \mathrm{Ab}$ \\
\hline Lutein & $3.55 \pm 0.77 \mathrm{Aa}$ & $3.06 \pm 1.28 \mathrm{Aa}$ & $2.94 \pm 0.24 \mathrm{Aa}$ & $2.22 \pm 0.94 \mathrm{Aa}$ \\
\hline$\beta$-carotene & $1.8 \pm 0.51 \mathrm{Bab}$ & $3.45 \pm 0.95 \mathrm{Aa}$ & $2.05 \pm 0.47 \mathrm{Ba}$ & $3.00 \pm 1.03 \mathrm{Aa}$ \\
\hline Vitamin E (mg.100g-1) & $0.49 \pm 0.08 \mathrm{Bc}$ & $5.57 \pm 0.34 \mathrm{Ab}$ & $0.44 \pm 0.09 \mathrm{Bc}$ & $6.68 \pm 0.69 \mathrm{Ab}$ \\
\hline$\alpha$-tocopherol & $0.30 \pm 0.12 \mathrm{Bb}$ & $1.57 \pm 0.55 \mathrm{Ab}$ & $0.20 \pm 0.18 \mathrm{Bb}$ & $1.54 \pm 0.40 \mathrm{Ab}$ \\
\hline$\alpha$-tocotrienol & - & - & - & - \\
\hline$\beta$-tocopherol & $0.02 \pm 0.01 \mathrm{Aa}$ & $0.09 \pm 0.01 \mathrm{Ac}$ & $0.04 \pm 0.02 \mathrm{Ba}$ & $0.15 \pm 0.01 \mathrm{Abc}$ \\
\hline$\beta$-tocotrienol & - & - & - & - \\
\hline$\gamma$-tocopherol & $0.05 \pm 0.01 \mathrm{Bb}$ & $2.49 \pm 0.53 \mathrm{Aa}$ & $0.11 \pm 0.03 \mathrm{Bab}$ & $3.08 \pm 0.57 \mathrm{Aa}$ \\
\hline$\gamma$-tocotrienol & $0.02 \pm 0.00 \mathrm{Aa}$ & $0.02 \pm 0.01 \mathrm{Aa}$ & $0.01 \pm 0.00 \mathrm{Ba}$ & - \\
\hline$\delta$-tocopherol & $0.01 \pm 0.00 \mathrm{Bb}$ & $1.14 \pm 0.52 \mathrm{Aa}$ & $0.03 \pm 0.01 \mathrm{Bab}$ & $1.55 \pm 0.20 \mathrm{Aa}$ \\
\hline$\delta$-tocotrienol & - & - & - & - \\
\hline Total Phenolics (mg GAE.g-1) & $3.60 \pm 0.79 \mathrm{Bc}$ & $27.1 \pm 1.91 \mathrm{Aa}$ & $4.65 \pm 0.42 \mathrm{Bc}$ & $45.5 \pm 3.47 \mathrm{Aa}$ \\
\hline \multicolumn{5}{|l|}{ Minerals (mg.100g-1) } \\
\hline $\mathrm{P}$ & $428.4 \pm 30.8 \mathrm{Aa}$ & $444.60 \pm 30.21 \mathrm{Aa}$ & $437.40 \pm 14.88 \mathrm{Aa}$ & $357.00 \pm 155.02 \mathrm{Aa}$ \\
\hline $\mathrm{K}$ & $3655.2 \pm 560.3 \mathrm{Aa}$ & $2569.80 \pm 395.56 \mathrm{Ba}$ & $2569.80 \pm 329.95 \mathrm{Aa}$ & $2459.00 \pm 372.65 \mathrm{Aa}$ \\
\hline $\mathrm{Ca}$ & $1131.6 \pm 12.8 \mathrm{Ab}$ & $553.80 \pm 73.69 \mathrm{Bb}$ & $1316.00 \pm 20.03 \mathrm{Ab}$ & $687.40 \pm 56.83 \mathrm{Bb}$ \\
\hline $\mathrm{Mg}$ & $330.8 \pm 7.1 \mathrm{Ab}$ & $181.60 \pm 56.75 \mathrm{Bb}$ & $240.00 \pm 30.00 \mathrm{Ab}$ & $129.00 \pm 19.24 \mathrm{Bb}$ \\
\hline $\mathrm{Cu}$ & $1,0 \pm 0.2 \mathrm{Aab}$ & $0.59 \pm 0.09 \mathrm{Aab}$ & $1.30 \pm 0.47 \mathrm{Aa}$ & $0.78 \pm 0.19 \mathrm{Ba}$ \\
\hline $\mathrm{Fe}$ & $36.3 \pm 5.4 \mathrm{Ab}$ & $20.88 \pm 2.69 \mathrm{Bb}$ & $89.82 \pm 45.66 \mathrm{Aa}$ & $70.66 \pm 26.96 \mathrm{Ba}$ \\
\hline $\mathrm{Zn}$ & $7.0 \pm 1.7 \mathrm{Ab}$ & $4.05 \pm 0.30 \mathrm{Ba}$ & $4.74 \pm 0.97 \mathrm{Aa}$ & $2.68 \pm 0.81 \mathrm{Bb}$ \\
\hline $\mathrm{Mn}$ & $11.6 \pm 5.6 \mathrm{Ab}$ & $7.10 \pm 2.76 \mathrm{Bb}$ & $21.55 \pm 1.66 \mathrm{Aa}$ & $11.72 \pm 1.21 \mathrm{Bab}$ \\
\hline
\end{tabular}

Values expressed in fresh matter; average of 3 repetitions for centesimal composition and minerals and average of 5 repetitions for bioactive compounds; data presented in mean \pm standard deviation. Means followed by different capital letters in the lines differ according to the treatment (raw or prepared) for each vegetable by the paired t-test. Means followed by different lowercase letters in the lines, comparing the vegetables within each treatment (raw or prepared) differ by Tukey test. TEV: total energetic value; P: phosphorus; $\mathrm{K}$ : potassium; Ca: calcium; Mg: magnesium; $\mathrm{Cu}$ : copper; Fe: iron; $\mathrm{Zn}$ : zinc; Mn: manganese. - = not found. 
higher lipid values after being cooked compared to

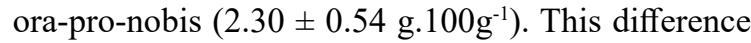
can be attributed to the lower amount of soybean oil added in the preparation of ora-pro-nobis, which also involved the addition of water.

The total carbohydrate concentration of raw ora-pro-nobis $\left(6.7\right.$ g. $\left.100 \mathrm{~g}^{-1}\right)$ was similar to that reported in wild mustard and serralha, but higher than that of capiçova. Among the cooked vegetables, there was no difference in the carbohydrate content. Raw and cooked non-conventional vegetables had low calories ( 29 to $78 \mathrm{Kcal} 100 \mathrm{~g}^{-1}$ ). However, it should be noted, that the energy value is overestimated in the present study, since total dietary fibers, which do not contribute to energy, were added to available carbohydrates.

$$
\text { Cooking promotes chemical, }
$$
physicochemical and structural changes in food components. According to the cooking time and the temperature employed, the destruction of microorganisms and enzymes, modifications of the sensorial and nutritional properties of the cooked product will take place (ARAÚJO et al., 2008). Cooking disaggregates plant structures, improving palatability and digestibility. In different cooking methods, the heat transfer forms, the temperature, the process duration, and the types of cooking are some of the factors responsible for the chemical and physical changes that can modify the nutritional value of the food (ALVES et al., 2011).

Vitamin and carotenoid concentration in nonconventional vegetables

The qualitative analysis of vitamins and carotenoids indicated the presence of the following components: $\beta$-carotene (retention time - $\mathrm{RT}=10.5$ $\mathrm{min})$; lutein $(\mathrm{RT}=3.5 \mathrm{~min})$; $\alpha$-tocopherol $(\mathrm{RT}=7$ $\min ) ; \quad \beta$-tocopherol (RT=10 $\mathrm{min}) ; \quad \gamma$-tocopherol $(\mathrm{RT}=11 \mathrm{~min}) ; \gamma$-tocotrienol $(\mathrm{RT}=12 \mathrm{~min}) ; \delta$-tocopherol (RT=17 min) (Figure 2 and 3 ).

The components $\alpha$-tocopherol, $\beta$-tocopherol, $\quad \gamma$-tocopherol, $\quad \gamma$-tocotrienol, $\delta$-tocopherol, $\beta$-carotene and lutein were reported in raw and cooked vegetables (Table 1). Carotenoid concentration increased after cooking, which could be attributed to the greater ease of extraction, since the heat treatment, in addition to inactivating oxidative enzymes, promotes the denaturation of carotenoid-protein complexes present in plant cells (RODRIGUEZ-AMAYA, 1996).

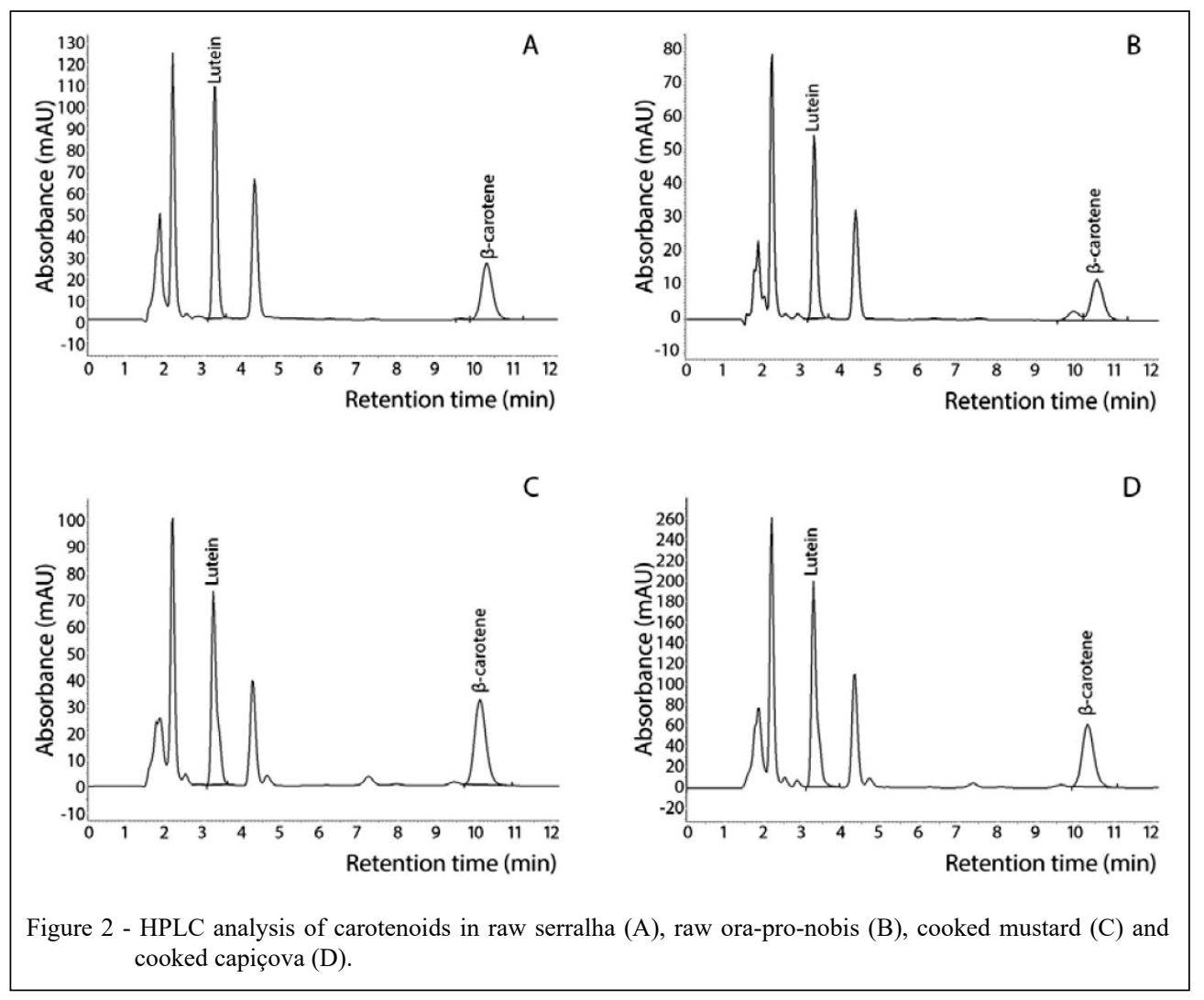

Ciência Rural, v.49, n.8, 2019. 
Concentration of vitamin $\mathrm{E}$ compounds varied among vegetables and cooking methods (Table 1). In raw vegetables, the major component of vitamin $\mathrm{E}$ was $\alpha$-tocopherol and in most cooked vegetables, $\gamma$-tocopherol presented higher concentrations (Figure 3 ). The increase of vitamin $\mathrm{E}$ in vegetables after cooking can be justified by the addition of soybean oil in the preparation, since oil is rich in vitamin $\mathrm{E}$.

\section{Concentration of total phenolic compounds}

Phenolic compounds concentrations in raw vegetables were reported in decreasing order: wild mustard, ora-pro-nobis, capiçova and serralha. In cooked vegetables, the concentrations of phenolic compounds were higher than in raw vegetables, in decreasing order: capiçova, ora-pro-nobis, wild mustard and serralha (Table 1). ROY et al. (2007) observed that lower temperatures $\left(50{ }^{\circ} \mathrm{C}\right)$ in the preparation of cooked vegetables preserved the phenolic compounds of spinach and cabbage (80 to $100 \%$ ). In our study, although the preparation temperature was higher (approximately $89^{\circ} \mathrm{C}$ ), an increase of these compounds was observed after cooking. The differences in the total phenolics concentration of raw and cooked vegetables are possibly due to increase to the efficiency in phenolic extraction after cooking.

\section{Occurrence and concentration of minerals}

We observed difference in the minerals concentration between raw and cooked nonconventional vegetables, except for the following minerals: $\mathrm{Mn}$ for ora-pro-nobis $(17.5 \pm 1.7$ and 15.2 $\pm 11.8 \mathrm{mg} .100 \mathrm{~g}^{-1}$, respectively); $\mathrm{Cu}$ for wild mustard $\left(0.6 \pm 0.1\right.$ and $\left.0.5 \pm 0.0 \mathrm{mg} .100 \mathrm{~g}^{-1}\right)$ and serralha $(1,0$ \pm 0.2 and $\left.0.59 \pm 0.09 \mathrm{mg} .100 \mathrm{~g}^{-1}\right)$ and $\mathrm{K}$ for capiçova $\left(2569.80 \pm 329.95\right.$ and $\left.2459.00 \pm 372.65 \mathrm{mg} .100 \mathrm{~g}^{-1}\right)$ $(\mathrm{P}>0.05)$ (Table 1). Cooked ora-pro-nobis and cooked wild mustard showed higher concentrations of $\mathrm{K}$ and $\mathrm{Ca}$, cooked serralha presented a higher $\mathrm{K}, \mathrm{Ca}$ and $\mathrm{P}$ content and capiçova presented $\mathrm{K}, \mathrm{Ca}, \mathrm{Fe}, \mathrm{Mn}$ and $\mathrm{Cu}$ in high concentration. Different cooking methods used of non-conventional vegetables may modify the minerals concentration (SANTOS et al., 2003). In addition, the extraction of minerals by water is determinant in these losses. Due to the fact that most of the minerals are reduced after cooking, it can be assumed that the lixiviation that occurs during boiling can be an important factor to explain these losses (COPETTI et al., 2010; ALVES et al., 2011).

Potential contribution of non-conventional vegetables to the supply of daily nutrient recommendations

The contribution of protein was, on average, $2.9 \%$ of the daily reference value (Table 2 ),

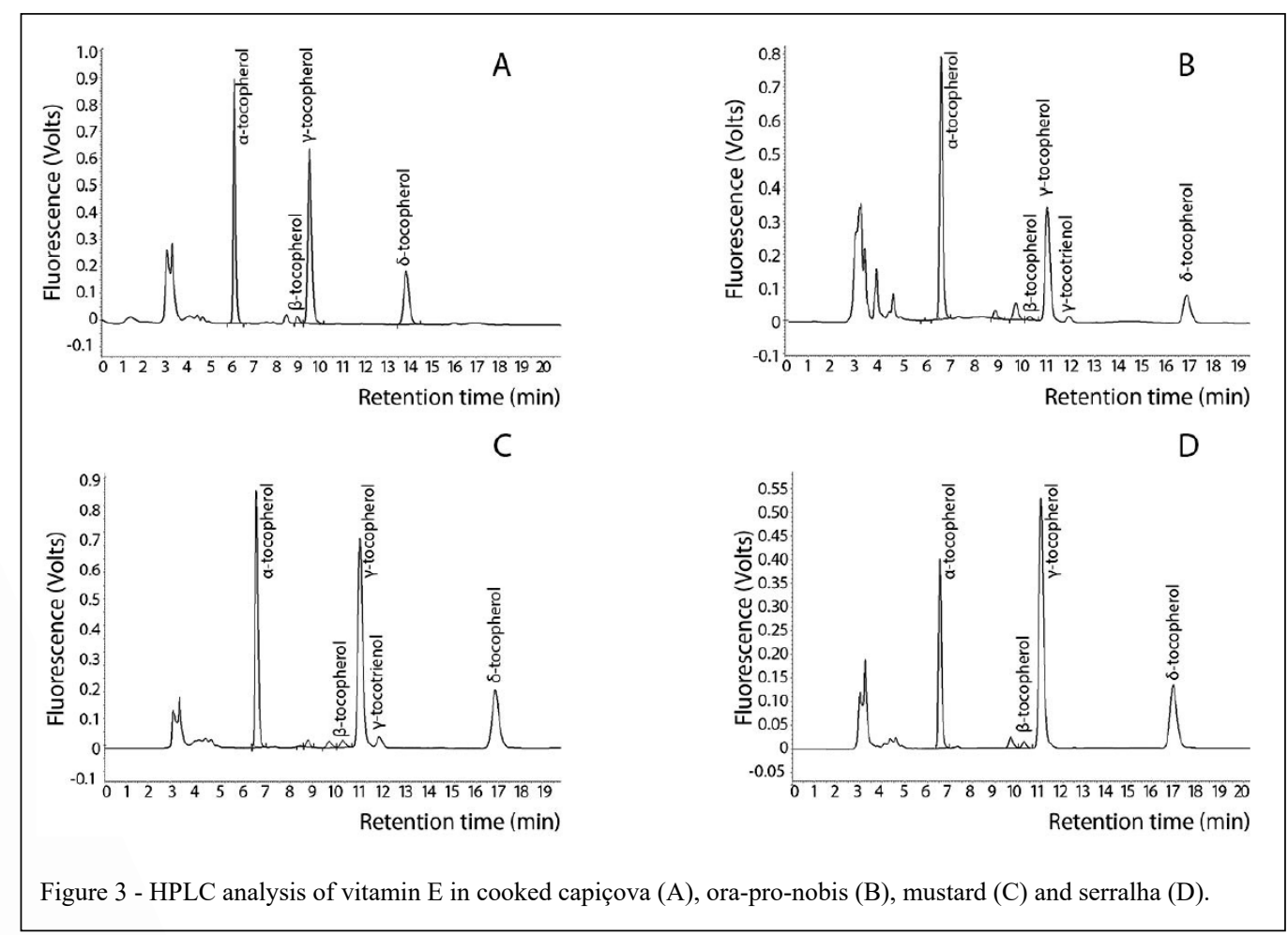

Ciência Rural, v.49, n.8, 2019. 
Table 2 - Potential of contribution of macronutrients and micronutrients of non-conventional vegetables of the rural area of Viçosa, Minas Gerais, Brazil.

\begin{tabular}{|c|c|c|c|}
\hline \multirow[t]{2}{*}{ Non-conventional vegetables } & \multirow[t]{2}{*}{ Nutrient } & \multicolumn{2}{|c|}{ 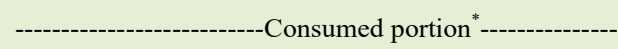 } \\
\hline & & Nutrient & $\% \mathrm{DV}$ \\
\hline \multirow{11}{*}{ Ora-pro-nobis } & Carbohydrates (g) & 4.4 & 3.4 \\
\hline & Protein (g) & 2.0 & 3.6 \\
\hline & Vitamin E (mg) & 2.1 & 14.0 \\
\hline & $\mathrm{Ca}(\mathrm{mg})$ & 399.8 & 40.0 \\
\hline & $\mathrm{Fe}(\mathrm{mg})$ & 13.9 & 173.7 \\
\hline & $\mathrm{Mg}(\mathrm{mg})$ & 75.9 & 18.1 \\
\hline & $\mathrm{Zn}(\mathrm{mg})$ & 0.2 & 1.8 \\
\hline & P (mg) & 298.9 & 42.7 \\
\hline & $\mathrm{Cu}(\mu \mathrm{g})$ & 68.6 & 7.6 \\
\hline & $\mathrm{Mn}(\mathrm{mg})$ & 1.5 & 65.0 \\
\hline & $\mathrm{K}(\mathrm{mg})$ & 221.5 & 4.7 \\
\hline \multirow{11}{*}{ Wild mustard } & Carbohydrates (g) & 3.0 & 2.3 \\
\hline & Protein (g) & 2.3 & 4.1 \\
\hline & Vitamin E (mg) & 2.4 & 16.0 \\
\hline & $\mathrm{Ca}(\mathrm{mg})$ & 79.9 & 8.0 \\
\hline & $\mathrm{Fe}(\mathrm{mg})$ & 31.8 & 397.5 \\
\hline & $\mathrm{Mg}(\mathrm{mg})$ & 16.9 & 4.0 \\
\hline & $\mathrm{Zn}(\mathrm{mg})$ & 0.2 & 1.8 \\
\hline & $\mathrm{P}(\mathrm{mg})$ & 407.7 & 58.2 \\
\hline & $\mathrm{Cu}(\mu \mathrm{g})$ & 45.5 & 5.1 \\
\hline & $\mathrm{Mn}(\mathrm{mg})$ & 0.3 & 13.0 \\
\hline & $\mathrm{K}(\mathrm{mg})$ & 228.4 & 4.9 \\
\hline \multirow{11}{*}{ Serralha } & Carbohydrates (g) & 2.8 & 2.2 \\
\hline & Protein (g) & 1.8 & 3.2 \\
\hline & Vitamin E (mg) & 1.3 & 8.7 \\
\hline & $\mathrm{Ca}(\mathrm{mg})$ & 44.2 & 4.4 \\
\hline & $\mathrm{Fe}(\mathrm{mg})$ & 16.6 & 207.5 \\
\hline & $\mathrm{Mg}(\mathrm{mg})$ & 14.5 & 3.5 \\
\hline & $\mathrm{Zn}(\mathrm{mg})$ & 0.3 & 2.7 \\
\hline & P (mg) & 355.2 & 50.7 \\
\hline & $\mathrm{Cu}(\mu \mathrm{g})$ & 48.0 & 5.3 \\
\hline & $\mathrm{Mn}(\mathrm{mg})$ & 0.6 & 26.1 \\
\hline & $\mathrm{K}(\mathrm{mg})$ & 204.8 & 4.4 \\
\hline \multirow{11}{*}{ Capiçova } & Carbohydrates (g) & 4.7 & 3.6 \\
\hline & Protein (g) & 2.0 & 3.6 \\
\hline & Vitamin E (mg) & 1.5 & 10.0 \\
\hline & $\mathrm{Ca}(\mathrm{mg})$ & 65.3 & 6.5 \\
\hline & $\mathrm{Fe}(\mathrm{mg})$ & 67.1 & 838.8 \\
\hline & $\mathrm{Mg}(\mathrm{mg})$ & 12.3 & 2.9 \\
\hline & $\mathrm{Zn}(\mathrm{mg})$ & 0.3 & 2.7 \\
\hline & P (mg) & 339.2 & 48.5 \\
\hline & $\mathrm{Cu}(\mu \mathrm{g})$ & 76.0 & 8.4 \\
\hline & $\mathrm{Mn}(\mathrm{mg})$ & 1.1 & 47.8 \\
\hline & $\mathrm{K}(\mathrm{mg})$ & 232.8 & 5.0 \\
\hline
\end{tabular}

DV: diary value; TEV: total energetic value; P: phosphorus; K: potassium; Ca: calcium; Mg: magnesium; Cu: copper; Fe: iron; Zn: zinc; Mn: manganese.

*Daily reference values based on IOM (2001) and IOM (2002/2005). Portion consumed by farmers: 98 g (ora-pro-nobis), 91 g (wild mustard), $80 \mathrm{~g}$ (serralha) and $95 \mathrm{~g}$ (capiçova). 
since the vegetables are not considered "sources" of this macronutrient. Portions consumed by farmers exceed the recommendation of iron intake. However, it is worth mentioning that the bioavailability of this nutrient in vegetables is influenced by heat treatment and/or processing and dietary factors that increase the absorption of iron, such as ascorbic acid and amino acids and those that decrease its absorption, such as phytates and polyphenols. Interaction of these enhancers and inhibitors is determinant in the bioavailability of iron, as well as the intrinsic factors of the organism, such as the nutritional status of the individual (BENITO \& MILLER, 1998).

It was also observed a potential of contribution of more than $30 \%$ of the recommendation for phosphorus in the consumed portions in the four vegetables studied, and for manganese in ora-pronobis and capiçova. Absorption and use of these minerals are influenced by other factors of the diet, such as the presence of modulators of absorption and/ or mineral utilization. Likewise, individual aspects may influence the bioavailability of these minerals (FAIRWEATHER-TAIT \& TEUCHER, 2002).

\section{CONCLUSION}

Non-conventional vegetables presented excellent nutritional value, highlighting ora-pronobis. Cooking increased the concentration of lipids, carotenoids, vitamin $\mathrm{E}$ and phenolic compounds. Besides, according to the type of preparation and portions consumed by family farmers, wild mustard, serralha and capiçova present high content of iron, phosphorus, manganese and magnesium. Ora-pronobis, besides these minerals, shows high content of calcium. Therefore, these non-conventional vegetables are important natural resources for human consumption and food diversification. Thus, it is essential to encourage the consumption and recovery of the traditional forms of cooking of family farmers.

\section{BIOETHICS AND BIOSSECURITY COMMITTEE APPROVAL}

This study was approved by the Human Research Ethics Committee of Universidade Federal de Viçosa (UFV) (Ref. No 121/2012) (CNS, 2012).

\section{ACKNOWLEDGEMENTS}

The authors thank the Coordenação de Aperfeiçoamento de Pessoal de Ensino Superior (CAPES, Brazil) and Conselho Nacional de Desenvolvimento Científico e Tecnológico (CNPq, Brazil) for financial support for conducting the study.

\section{DECLARATION OF CONFLICT OF INTERESTS}

The authors declare no conflict of interest. The founding sponsors had no role in the design of the study; in the collection, analyses, or interpretation of data; in the writing of the manuscript, and in the decision to publish the results.

\section{AUTHORS' CONTRIBUTIONS}

The authors contributed equally to the manuscript.

\section{REFERENCES}

ALVES, NEG et al. Effect of different cooking methods on the nutrient contents in broccoli (Brassica oleracea L. var. italica). Revista do Instituto Adolfo Lutz, v.70, n.4, p.507-513, 2011.

AOAC. Official methods of analysis of AOAC international: Agricultural chemicals, contaminants, drugs. 2012, Gaithersburg: AOAC International.

ARAÚJO, WMC et al. Alquimia dos alimentos. $2^{\mathrm{a}}$ ed. Brasília (DF): Editora SENA; 2008.

BARREIRA, T. et al. Diversity and equivalence of unconventional food plants in rural zone of Viçosa, Minas Gerais, Brazil. Revista Brasileira de Plantas Medicinais, v.17, n.4, supl. 2, p.964-974, 2015.

BARRETT, DM; BEAULIEU, JC; SHEWFELT, R. Color, flavor, texture, and nutritional quality of fresh-cut fruits and vegetables: desirable levels, instrumental and sensory measurement, and the effects of processing. Critical Reviews in Food Science and Nutrition, v.50, n.5, p.369-389, 2010

BENITO, P; MILLER, D. Iron absorption and bioavailability: an updated review. Nutrition Research, v.18, n.3, p.581-603, 1998.

CAMPOS, FM et al. Optimization of methodology to analyze ascorbic and dehydroascorbic acid in vegetables. Química Nova, v.32, n.1, p.87-91, 2009.

CARDOSO, PC et al. Carotenos provitamínicos A em hortaliças preparadas em unidades produtoras de refeições comerciais. Boletim do Centro de Pesquisa de Processamento de Alimentos, v. 27, n. 1,2009

COPETTI, C; OLIVEIRA, VRD; KIRINUS, P. Evaluation of potassium in vegetables submitted to different cooking methods and their possible use in renal diet. Revista de Nutrição, v.23, n.5, p.831-838, 2010.

FAIRWEATHER-TAIT, SJ; TEUCHER, B. Calcium bioavailability in relation to bone health. International journal for vitamin and nutrition research, v.72, n.1, p.13-18, 2002.

GOMES, JC; OLIVEIRA, GF. Fotometria de Chama e Espectrofotometria de Absorção Atômica. In: GOMES, JC. e OLIVEIRA, GF. (Ed.). Análises físico-químicas de alimentos. Viçosa: Editora UFV, 2011. p.244.

INSTITUTE OF MEDICINE: Food and Nutrition Board. Dietary Reference Intakes for Vitamin A, Vitamin K, Arsenic, Boron, Chromium, Copper, Iodine, Iron, Manganese, Molybdenum, 
Nickel, Silicon, Vanadium, and Zinc. The National Academies Press. Washington, DC. 2001.

JIMOH, FO; AFOLAYAN, AAAAJ. Comparison of the nutritive value, antioxidant and antibacterial activities of Sonchus asper and Sonchus oleraceus. Records of Natural Products, v.5, n.1, p.29, 2011.

KINUPP, VF; LORENZI, H. Plantas alimentícias não convencionais (PANC) no Brasil: guia de identificação, aspectos nutricionais e receitas ilustradas. Instituto Plantarum de Estudos da Flora Ltda, 2014.

MAPA - Ministério da Agricultura Pecuária e Abastecimento. Manual de hortaliças não convencionais. Secretaria de Desenvolvimento Agropecuário e Cooperativismo. Brasília: Mapa/ACS 2010.

MARTINEVSKI, CS et al. Utilização de bertalha (Anredera Cordifola (Ten.) Steenis) e ora-pro-nobis (Pereskia Aculeata Mill.) na elaboração de pães. Alimentos e Nutrição Araraquara, v.24, n.3, p.272, 2013.

MERTZ, C. et al. Phenolic compounds, carotenoids and antioxidant activity of three tropical fruits. Journal of Food Composition and Analysis, v.22, n.5, p.381-387, 2009.

OLIVEIRA, HAB et al. Habits and food crops on the consumption of non-conventional vegetables by family farmers. Revista Agrária Acadêmica, v.2, n.3, 2019.

PAULA FILHO, GX et al. Chemical composition, carotenoids, vitamins and minerals in wild mustard collected in native areas Horticultura Brasileira, v.36, n.1, 2018.

PINHEIRO-SANT'ANA, HM et al. Method for simultaneous analysis of eight vitamin $\mathrm{E}$ isomers in various foods by high performance liquid chromatography and fluorescence detection. Journal of Chromatography A, v.1218, n.47, p.8496-8502, 2011.

PINHEIRO-SANT'ANA, HM et al. Carotenoid retention and vitamin A value in carrot (Daucus carota L.) prepared by food service. Food Chemistry, v.61, n.1, p.145-151, 1998.
PLATEL, K.; SRINIVASAN, K. Bioavailability of micronutrients from plant foods: an update. Critical Reviews in Food Science and Nutrition, v.56, n.10, p.1608-1619, 2016.

PODSĘDEK, A. Natural antioxidants and antioxidant capacity of Brassica vegetables: A review. LWT-Food Science and Technology, v.40, n.1, p.1-11, 2007.

RODRIGUEZ-AMAYA, DB. Assessment of the provitamin A contents of foods - the Brazilian experience. Journal of Food Composition and Analysis, v.9, n.3, p.196-230, 1996.

A guide to carotenoid analysis in foods. Ilsi Press Washington Ed. Washington DC 2001.

ROY, MK et al. Antioxidant potential, anti-proliferative activities, and phenolic content in water-soluble fractions of some commonly consumed vegetables: Effects of thermal treatment. Food Chemistry, v.103, n.1, p.106-114, 2007.

SANTOS, MATD; ABREU, CMPD; CARVALHO, VDD. Effect of different boiling times on contents of minerals in leaves of broccoli, cauliflower and cabbage (Brassica oleracea L.). 2003.

SINGLETON, VL; ORTHOFER, R; LAMUELA-RAVENTOS, RM. Analysis of total phenols and other oxidation substrates and antioxidants by means of Folin-Ciocalteu reagent. Methods in Enzymology, v.299, p.152-178, 1999.

SOUZA, RCR et al.. Aperfeiçoamento e Difusão de Fogões a Lenha de Queima Limpa no Estado do Amazonas. In: Anais do $3^{\circ}$ Encontro de Energia no Meio Rural. Campinas, 2003.

VIANA, $M$ et al. Phytochemical composition and antioxidant potential of unconventional vegetables. Horticultura Brasileira, v.33, p.504-509, 2015.

YOUNG, VR; PELLETT, PL. Plant proteins in relation to human protein and amino acid nutrition. The American Journal of Clinical Nutrition, v.59, n.5, p.1203S-1212S, 1994. 